\title{
Moving Along the Belt and Road: Implications of China's “One Belt, One Road” Strategies on Chinese Migration
}

\author{
Raya Muttarak
}

Wittgenstein Centre for Demography and Global Human Capital (IIASA, VID/ÖAW and WU), International Institute for Applied Systems Analysis, Austria and School of International Development, University of East Anglia, United Kingdom

muttarak@iiasa.ac.at

\section{沿“一帶一路”的移動: “一帶一路” 戰略對中 國人口遷移影響}

\section{Raya Muttarak}

英國東英格蘭大學

* Dr Raya Muttarak is a Senior Lecturer in Geography and International Development at the University of East Anglia, UK. She is also an affiliated research scholar at the Wittgenstein Centre for Demography and Global Human Capital (IIASA, VID/ÖAW and WU), International Institute for Applied Systems Analysis (IIASA), Austria. She is a founding member of the scientific group "One-Belt-One-Road Strategy: Implications on Population Dynamics and SocioEcological Impacts" of the Asian Population Association. Her research interests crosscut and integrate the fields of social inequality, health, differential vulnerability to environmental change and migration.

Raya Muttarak, 東英格蘭大學地理學和國際發展領域高級講師, 維也納維特 根斯坦人口和人力資本研究中心高級研究員, 國際應用系統分析研究所高級 研究員。亞洲人口學會““一帶一路” 戰略：人口動態變化和社會生態影響 的啟示” 骨幹成員。主要研究領域包括社會公平、健康、環境變化的脆弱性 差異、人口遷移等。 


\begin{abstract}
Along with the flows of China's foreign direct investment following the newly implemented "One Belt, One Road" strategy by the Chinese government comes movement of state employees, entrepreneurs, workers and accompanying family members to respective countries along the Belt and Road. It is not clear how large the Chinese migration flows into these countries will be, who they will be comprised of, how the public reception of the host society will be and how well the migrants will be integrated in the destination country. Based on extant data and literature on current Chinese migration, this paper describes trends and patterns of recent Chinese migration in Africa and Asia, analyzes host country public perceptions on China, and investigates integration patterns of Chinese migrants. Given that the "One Belt, One Road" strategy was officially endorsed in 2015, it is still early to analyze its impacts on Chinese migration in the respective countries. Considering earlier Chinese overseas migration of the past decades, this paper presents potential migration and integration patterns one may expect following the Belt and Road initiative.
\end{abstract}

\title{
Keywords
}

China - integration - One Belt One Road - public attitudes - migrants - migration

\section{摘要}

中國政府提出的「一帶一路」戰略帶來大量的對外直接投資, 隨之形成了沿 $\ulcorner$ 一帶一路」的人口遷移流, 這些遷移人口包括雇員、企業家、勞動力及其家 庭成員等。來自中國的大量遷移人口將在沿「一帶一路」國家形成怎樣的遷移 格局? 誰會成為這些遷移者? 沿「一帶一路」國家的主流社會對這些遷移者的 公眾反應會是怎樣? 遷移者怎樣才能很好地融入遷入地國家? 這些問題都有待 回答。根據中國當前人口遷移的相關數據和文獻, 本研究分析了中國在亞洲、 非洲的人口遷移趨勢和格局, 以及沿 “一帶一路” 國家對中國的公眾感知和中 國遷移者的融入情況。由於中國官方自 2015 年才正式推動“一帶一路” 戰略, 因此這方面的研究也才剛起步。但是過去關於海外華人的研究, 為未來的發展 提供了可能的參考模式。

\section{關鍵詞}

态度、中国、融合、一带一路、迁移者、迁移 


\section{Introduction}

During his visits to Kazakhstan and Indonesia in 2013, President Xi Jinping called for the establishment of a new regional cooperation model and creation of the Asian Infrastructure Development Bank. Subsequently, in March 2015, detailed plans for the "One Belt, One Road" (овов) or the "Belt and Road" Initiative were laid out in a White Paper.' Set to promote regional integration through a network of trade routes, political cooperation and cultural exchange, the овов initiative spans 65 countries through the "Silk Road Economic Belt" traversing Central Asia and West Asia linking China with Europe, and a " $21^{\text {st }}$ Century Maritime Silk Road" through Southeast and South Asia connecting China with Europe and Africa. Accordingly, plans to connect facilities including the construction of infrastructure such as railways, highways, air routes, ports and telecommunications are a priority area of овов.

Although the Belt and Road initiative was made official only recently, China's economic and trade expansion, for instance in Africa, dates back to the mid1990s. Particularly after the official adoption of China's "Going Out" strategy in $1999,{ }^{2}$ China's growing trade relationship has allowed African countries to diversify their export base away from such advanced economies as the United States and the European Union. ${ }^{3}$ Likewise, China's economic influence and investments have been prominent in Southeast Asia and Central Asia since the early $2000{ }^{4}{ }^{4}$ Chinese foreign direct investment is evident not only in physical infrastructure but also in small scale manufacturing enterprises and retail traders. The latter, being operated by Chinese migrants, is present pretty much in every economy where Chinese investment and development projects are located. ${ }^{5}$

1 NDRC, "Vision and Actions on Jointly Building Silk Road Economic Belt and 21st-Century Maritime Silk Road" (Beijing: National Development and Reform Commission [NDRC], March 28, 2015), http://en.ndrc.gov.cn/newsrelease/201503/t20150330_669367.html.

2 Emily T. Yeh and Elizabeth Wharton, "Going West and Going Out: Discourses, Migrants, and Models in Chinese Development," Eurasian Geography and Economics 57, 3 (May 3, 2016): 286-315, doi:10.1080/15387216.2016.1235982.

3 Paulo Drummond and Estelle Xue Liu, "Africa's Rising Exposure to China: How Large Are Spillovers Through Trade?," IMF Working Paper (Washington, DC: International Monetary Fund, November 2013), https://www.imf.org/external/pubs/ft/wp/2013/wp13250.pdf.

4 Elizabeth Economy, "China's Rise in Southeast Asia: Implications for the United States," Journal of Contemporary China 14, 44 (August 1, 2005): 409-25, doi: 10.1080/10670560500115184; Sébastien Peyrouse, "Discussing China: Sinophilia and Sinophobia in Central Asia," Journal of Eurasian Studies 7, 1 (January 2016): 14-23, doi:10.1016/j.euras.2015.10.003.

5 Raphael Kaplinsky and Mike Morris, "Chinese FDI in Sub-Saharan Africa: Engaging with Large Dragons," The European Journal of Development Research 21, 4 (September 1, 2009): 551-69, doi:10.1057/ejdr.2009.24. 
It is not uncommon for former employees of major state-funded projects to stay on, legally or illegally, and start new business enterprises. Seeing market opportunities, new migrants were brought in through family links to join existing businesses or establish new ones. ${ }^{6}$

The impacts of China's growing presence in these regions thus go beyond the macro-economic effects such as trade flows, commodity prices and economic growth that are commonly studied in the literature. ${ }^{7}$ Along with investments and trade-either state-owned or private-comes movement of labor, entrepreneurs, accompanying family members and students. That China's economic development activities go hand in hand with migration is reflected in previous development policies. Similar to the strategy of "Going Out," the "Open up the West" or "Going West" strategy announced in 1999 was implemented to address uneven development and regional inequality particularly in the Western part of China. This strategy is characterized by an explicit policy facilitating the movement of Chinese, particularly Han Chinese, from other areas into the West. ${ }^{8}$ The building of infrastructure and transportation networks along the Belt and Road countries coupled with increase in direct investments from state-owned and private enterprises will promote global trade and consequently more migration of manufacturers, entrepreneurs and the like among these countries.

Correspondingly, it is important to understand what the social, economic and demographic consequences of Chinese outmigration in the Belt and Road countries are, especially if this migration can potentially increase to large scale. Certain research questions such as public attitudes towards immigrants, migrants' integration and impacts of migration on local economy are of policy interest. Since the овов strategy has been officially endorsed only since 2015, unsurprisingly there is little research on its consequences. Drawing upon evidence of recent Chinese outmigration to Africa and Asia, this paper proposes key research areas needed to understand the potential consequences

6 Gregor Dobler, "Chinese Shops and the Formation of a Chinese Expatriate Community in Namibia," The China Quarterly, no. 199 (2009): 707-27.

7 Rhys Jenkins and Chris Edwards, "The Economic Impacts of China and India on SubSaharan Africa: Trends and Prospects," Journal of Asian Economics 17, 2 (April 2006): 207-25, doi:10.1016/j.asieco.2006.02.002; Ali Zafar, "The Growing Relationship Between China and Sub-Saharan Africa: Macroeconomic, Trade, Investment, and Aid Links," The World Bank Research Observer 22, 1 (March 1, 2007): 103-30, doi:10.1093/wbro/lkmoo1; Hany Besada, Yang Wang, and John Whalley, "China's Growing Economic Activity In Africa," in China's Integration into the World Economy, ed. John Whalley (Singapore: World Scientific, 2011), 221-54, https://ideas.repec.org/h/wsi/wschap/9789814304795_ooog.html.

8 Yeh and Wharton, "Going West and Going Out." 
of the овов strategy. The rest of the paper is organized as follows. The next section describes recent trends and patterns of Chinese migration overseas. The subsequent section discusses implications of Chinese migration in the овоR countries in terms of public opinions of the host country towards Chinese migrants and integration of the migrants. The last section offers a conclusion.

\section{Trends and Patterns of Chinese Outmigration}

China's migration was tightly controlled during the first three decades after the founding of the People's Republic of China (PRC) in 1949. During this period, Chinese emigrants comprised those who left to work on statesponsored projects or those who left illegally. ${ }^{9}$ In the late 1950s, approximately 150,000 workers were sent to newly independent African countries to work in state-to-state cooperation on agriculture, technology and infrastructure projects. Most of these workers returned to China after the projects finished. ${ }^{10}$ The historical economic reform in 1978 led to an opening up to the outside world and liberalization of exit controls. As a consequence, there had been a gradual increase in legal migration of researchers and students and migration of poor people, often illegally, to North America and Western Europe. Likewise, the continuing economic growth also promoted migration flows through immigrant investor channels to other countries in Asia, Latin America and Africa. ${ }^{11}$

As presented in Figure 1, based on the total migrant stock estimated by the United Nations (UN) Population Division, ${ }^{12}$ the number of Chinese migrants has been rising steadily. The number of people born in China living abroad worldwide rose from 4.2 million in 1990 to over 9.5 million in 2015. The increase can be observed in all world regions as a result of China's economic growth and the increasing skills and financial resources of migrants enabling them to

Tony Fielding, Asian Migrations: Social and Geographical Mobilities in Southeast, East, and Northeast Asia (New York, NY: Routledge, 2015).

10 Yoon Jung Park, "Chinese Migration in Africa," China in Africa Project (South African Institute of International Affairs, 2009), https://www.saiia.org.za/occasional-papers/132 -chinese-migration-in-africa/file.

11 Biao Xiang, "The Rise of China: Changing Patterns of out-Migration and Identity Implications," in Handbook of Chinese Migration: Identity and Wellbeing, ed. Robyn R. Iredale and Fei Guo (Cheltenham, uk: Edward Elgar Publishing, 2015), 278-94.

Ibid. 


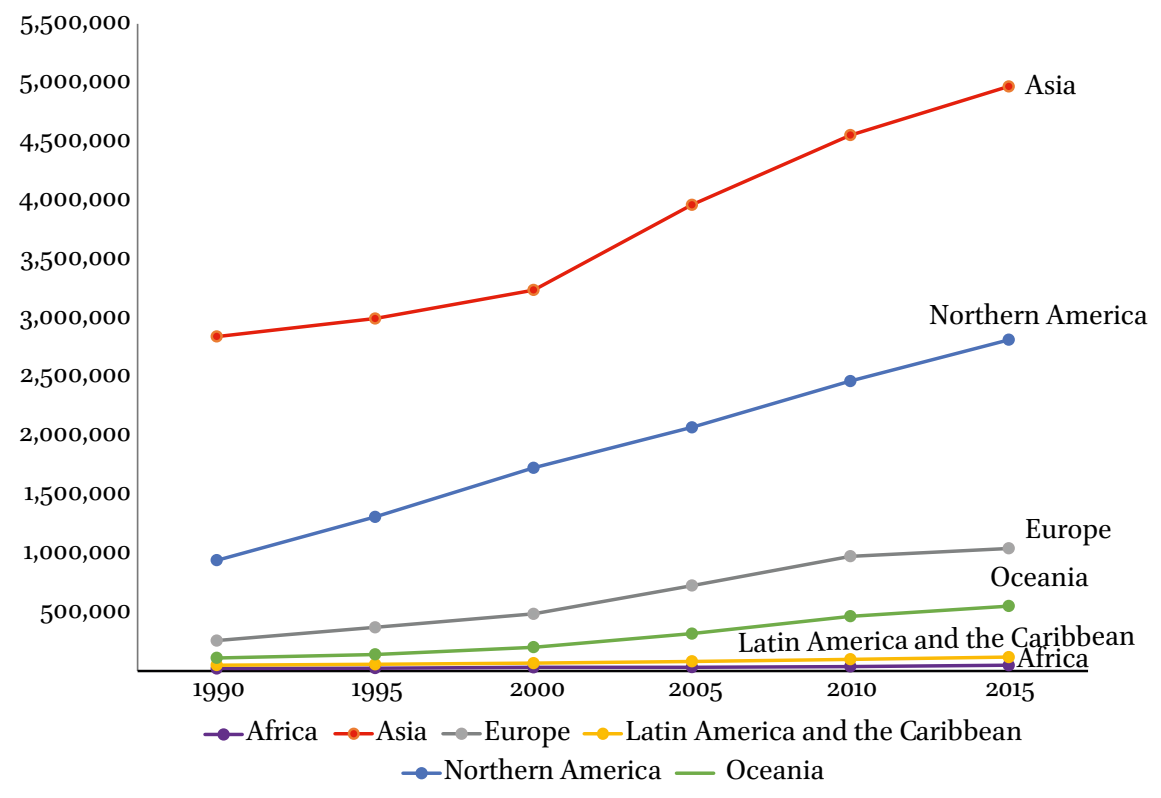

FIGURE 1 Stock of migrants from China in different world regions: 1990-2015. SOURCE: UNITED NATIONS, DEPARTMENT OF ECONOMIC AND SOCIAL AFFAIRS. ${ }^{13}$

migrate. ${ }^{14}$ Focusing particularly on the regions along the Belt and Road and Africa (where Chinese foreign direct investment is concentrated), Figure 2 shows that the stock of migrants from China has increased substantially in these regions in 2015 as compared to the early 1990s. The largest percentage increase can be observed in Western Asia (524\%), Eastern Africa (297\%) and Southern Africa (126\%). The rising number of Chinese migrants in Africa corresponds with the growth of trade and China's investment in these countries. ${ }^{15}$ Note that the increase of Chinese migrant stock is not limited to the овов regions but is also seen in other parts of the world such as Southern Europe (781\%), Australia and New Zealand (420\%) and North America (198\%).

13 "Trends in International Migrant Stock: Migrants by Destination and Origin" (New York: United Nations, Department of Economic and Social Affairs, 2015), http://www.un.org/ en/development/desa/population/migration/data/estimates2/estimates15.shtml.

14 Xiang, "The Rise of China: Changing Patterns of out-Migration and Identity Implications."

15 Giles Mohan and May Tan-Mullins, "Chinese Migrants in Africa as New Agents of Development? An Analytical Framework," in The Power of the Chinese Dragon: Implications for African Development and Economic Growth, ed. Spencer Henson and O. Fiona Yap, vol. 3 of Palgrave Readers in Economics (London: Palgrave Macmillan UK, 2016), 174-98, doi:10.1007/978-1-137-57449-7_8. 

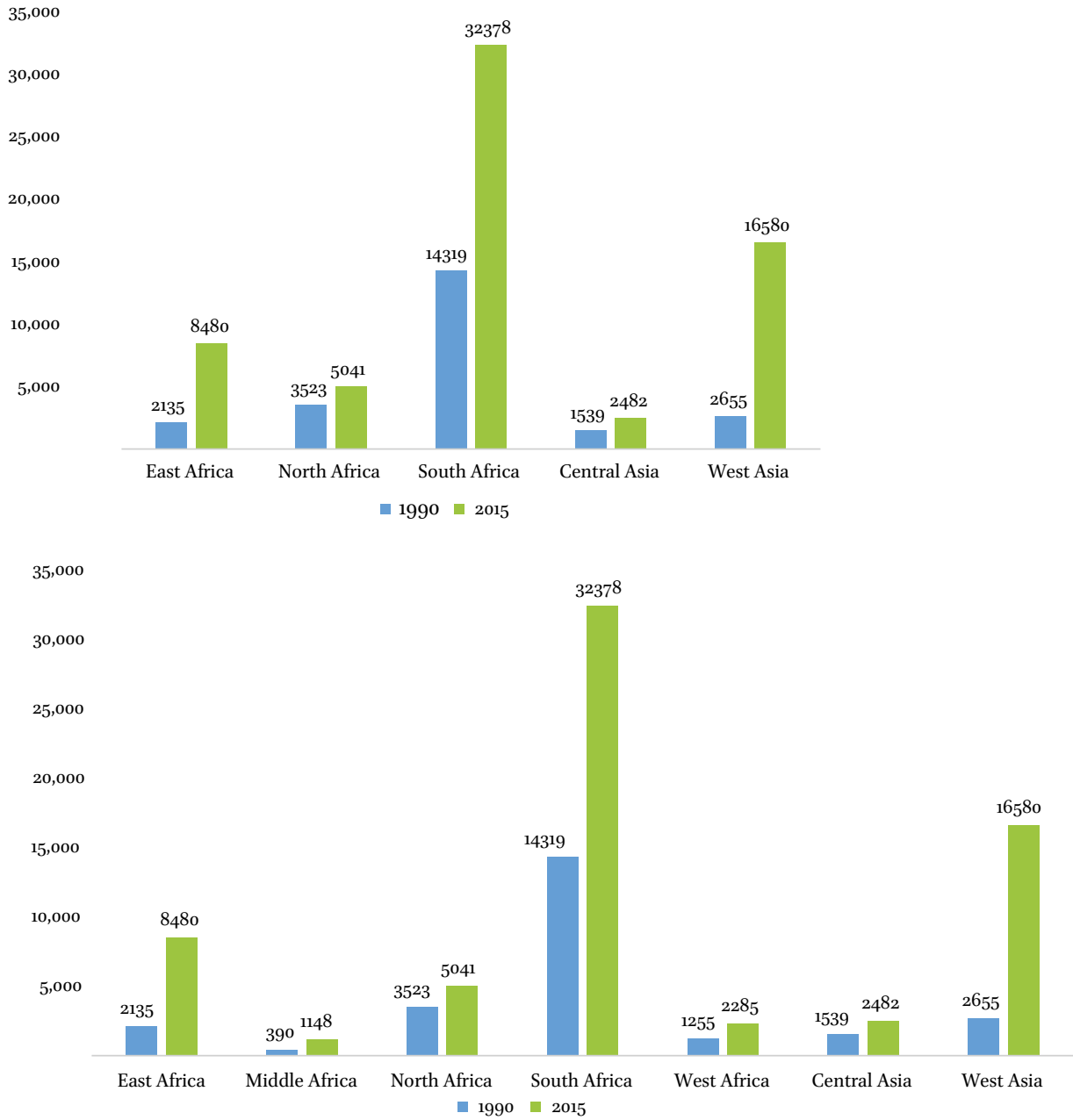

FIGURE 2 Changes in Chinese migrant stocks in the Belt and Road regions between 1990 and 2015.

SOURCE: UNITED NATIONS, DEPARTMENT OF ECONOMIC AND SOCIAL AFFAIRS. ${ }^{16}$

Although there has been an increase in the number of Chinese overseas worldwide, the patterns of Chinese migration to the овов and non-овов countries may differ. Indeed, the composition of Chinese migrants to high income countries has changed over time. ${ }^{17}$ High-income countries like Australia, New

16 "Trends in International Migrant Stock: Migrants by Destination and Origin."

17 BiaoXiang, "Emigration Trends and Policies in China: Movement of the Wealthy and Highly Skilled," Transatlantic Council on Migration (Washington, DC: Migration Policy, February 
Zealand, Japan, USA, Canada and countries in Europe have benefitted from the immigration of wealthy and highly skilled Chinese emigrants since the late 200os. Wealthy and well-educated Chinese, as well as students, prefer developed countries in the global north, citing children's education, quality of life and economic and social uncertainties in China as the main reasons of emigration. ${ }^{18}$

On the other hand, Chinese migration to developing countries in Africa is often undertaken by Chinese civil servants, temporary labor migrants linked to publicly-funded Chinese investment projects, small-time entrepreneurs, in-transit migrants and agricultural workers. ${ }^{19}$ In this setting, many migrants who have established small businesses in Africa usually originally migrated to work on large state-backed projects. Seeing business opportunities in the region, these migrants stayed on and started inviting friends, family members and people from their hometown to join them. ${ }^{20}$ The arrival of more migrants opened up new business and employment opportunities in small enterprises both in the service sector, such as Chinese restaurants, shops and even brothels, and in small scale manufacturing plants. ${ }^{21}$ These migration patterns may also apply tо овов countries where Chinese foreign direct investment and development projects are concentrated. Indeed, there is evidence that in developing countries, particularly in Africa, Chinese workers fill up about $50 \%$ of low-skilled and 90\% of professional and managerial positions in Chinese construction firms. ${ }^{22}$ The regular use of labor from China by Chinese companies overseas $^{23}$ implies a potentially similar migration pattern of Chinese workers (and subsequently their family members) in the овов countries.

Estimating exactly how many Chinese migrants currently are or are expected to be in the овов countries is, however, a difficult task. First, available data

5, 2016), http://www.migrationpolicy.org/research/emigration-trends-and-policies-china -movement-wealthy-and-highly-skilled.

18 Xiang, "The Rise of China, Changing Patterns of out-Migration and Identity Implications."

19 Giles Mohan et al., Chinese Migrants and Africa's Development: New Imperialists or Agents of Change? (London: Zed Books Ltd, 2014).

$20 \quad$ Yeh and Wharton, "Going West and Going Out."

21 Mohan et al., Chinese Migrants and Africa's Development.

22 Chuan Chen, Andrea Goldstein, and Ryan Orr, "Local Operations of Chinese Construction Firms in Africa: An Empirical Survey," The Journal of Construction Management (2009): $75^{-89}$.

23 Barry Sautman and Hairong Yan, "Localizing Chinese Enterprises in Africa: From Myths to Policies," HKUST IEMS Thought Leadership Brief Series (HKUST Institute for Emerging Market Studies, February 2015), http://econpapers.repec.org/paper/hkubriefs/201505 .htm. 
on the number of Chinese migrants are often speculative. Guesstimates of the number of Chinese migrant range from 583,050 to 820,050 between $2003-2008$ in Africa ${ }^{24}$ and 2.3 to 2.65 million in Southeast Asia in 2006. ${ }^{25}$

Although the data from the UN Population Division ${ }^{26}$ allow us to gauge the number of Chinese-born overseas, many scholars have questioned the reliability of migration statistics of the receiving countries. ${ }^{27}$ Not only are official data collection systems questionable, but undocumented migrants are also difficult to account for in the state surveillance system. ${ }^{28}$ The challenges of poor data quality and lack of accurate migration statistics are seen in the ово as well. Second, extant migration data generally are stock data representing the total number of international migrants in a particular country at a given point in time. Stock data thus only inform about the number of, for example, a foreign-born population in a given country regardless of when they entered that country. Flow data that represent the number of persons arriving or leaving a particular country during a certain period of time, on the other hand, are dynamics allowing for deeper insights into migration patterns and population behavior. However, bilateral migration flow data are scarce since data collections systems for migration flow data are not available in many countries. ${ }^{29}$

The paucity of reliable information on the number of Chinese migrants overseas can pose challenges both in the host society and for China. The large number of Chinese migrants often exaggerated by the media in the host countries can influence public opinions towards migrants. A lack of knowledge about the number of migrant inflows and outflows, types of migration (e.g. temporary labor migrants, economic migrants), occupation (e.g. entrepreneur,

24 Park, "Chinese Migration in Africa."

25 Guotu Zhuang and Wang Wangbo, "Migration and Trade: The Role of Overseas Chinese in Economic Relations between China and Southeast Asia," International Journal of China Studies 1, 1 (2010): 174-93.

26 United Nations, "Trends in International Migrant Stock: Migrants by Destination and Origin."

27 Laurence J.C. Ma, "Space Place and Transnationalism in the Chinese Diaspora," in The Chinese Diaspora: Space, Place, Mobility, and Identity, ed. Laurence J.C. Ma and Carolyn L. Cartier (Lanham, MD: Rowman \& Littlefield, 2002), 1-50; Mohan and Tan-Mullins, "Chinese Migrants in Africa as New Agents of Development?"

28 Emmanuel Ma Mung, "Chinese Migration and China Foreign Policy in Africa," Journal of Chinese Overseas 4, 1 (May 1, 2008): 91-109, doi:10.1163/179325408788691471.

29 Guy J. Abel, "Estimating Global Migration Flow Tables Using Place of Birth Data," Demographic Research 28, 18 (March 15, 2013): 505-46, doi:10.4054/DemRes.2013.28.18. 
manager, laborer) and socio-demographic composition (e.g. age, sex, education) of the Chinese migrants makes it difficult for policy makers to design targeted policies and programs. For instance, the policy of the Chinese government instituted in 2002 to encourage high-skilled migrants, especially in science and technology sectors to return to China ${ }^{30}$ would need to locate where these migrants are. For the host countries, access to reliable and timely international migration flows can help informing the planning of access to basic social services, housing, taxation systems and so on.

Furthermore, to understand the impacts of Chinese migration in овов countries, it is fundamental to know the size, composition and distribution of these migrant groups. This calls for future research that addresses the knowledge gap in describing trends and patterns and estimating the magnitude of migration of Chinese people to the Belt and the Road countries. Indeed, the recent estimates of global bilateral migration flows, both the total and categorized by gender by Abel and Sander ${ }^{31}$ and Abel, ${ }^{32}$ respectively, allow us to understand the dynamics of migration patterns of Chinese migrants and their gender composition. Further disaggregation by other socio-demographic characteristics such as age, education and occupation will help identify who the migrants are. To supplement official migration statistics, alternative data sources or "big data" can be used to study human mobility. Recent studies have introduced big data such as email log in locations ${ }^{33}$ or mobile phone data ${ }^{34}$ to estimate population movement and distribution. This can be an alternative data source for estimating Chinese migration flows.

$30 \quad$ Priyanka Debnath, "Leveraging Return Migration for Development: The Role of Countries of Origin," KNomad Working Paper Series (Washington, DC: Global Knowledge Partnership on Migration and Development (KNOMAD), 2016), http://www.knomad.org/docs/ integration_issues/WP\%2oLeveraging\%2oReturn\%2oMigration\%2ofor\%2oDevelopment\%20-\%20The\%2oRole\%20of\%2oCountries\%20of\%2oOrigin.pdf.

31 Guy J. Abel and Nikola Sander, "Quantifying Global International Migration Flows," Science 343, 6178 (March 2014): 1520-22, doi:10.1126/science.1248676.

32 Guy J. Abel, "Estimates of Global Bilateral Migration Flows by Gender between 1960 and 2015," International Migration Review (2017), doi:10.1111/imre.12327.

33 Emilio Zagheni and Ingmar Weber, "You Are Where You E-Mail: Using E-Mail Data to Estimate International Migration Rates," in Proceedings of the 4th Annual ACM Web Science Conference (АСM, 2012), 348-351, http://dl.acm.org/citation.cfm?id=2380764.

34 Pierre Deville et al., "Dynamic Population Mapping Using Mobile Phone Data," Proceedings of the National Academy of Sciences 111, 45 (November 11, 2014): 15888-93, doi:10.1073/ pnas.1408439111. 


\section{Implications of Chinese Migration in the Belt and Road Countries}

Similar to classical migration studies, how Chinese migrants are welcomed and integrated into the host society is a fundamental research question. Studies on public attitudes to immigration in Europe and North America commonly explain that attitudes are shaped by two dimensions: 1) native-born citizens' individual self-interest e.g. competition over resources, impacts on the local labor market, fiscal burden; and 2) sociopsychological aspects e.g. cultural values and beliefs and group-specific stereotypes. ${ }^{35}$ Attitudes towards immigrants vary with the skill levels, ethno-religious composition and legal status of the immigrants as well as socio-demographic characteristics of the natives and socio-economic contexts of the receiving countries. ${ }^{36}$ Given that most immigrants in advanced economies are low-skilled foreign workers from low-income countries, it has been commonly found that natives from lower socio-economic background e.g. the less educated, the unemployed or unskilled laborers are more likely to report unfavorable attitudes towards immigration and immigrants. ${ }^{37} \mathrm{On}$ the other hand, it is widely perceived that skilled migrants contribute substantially to tax revenues and hence are often viewed positively by the citizens of the destination countries. ${ }^{38}$

Similarly, the patterns of public attitudes towards Chinese migrants in the Belt and Road countries are likely to depend on the skill levels of the migrants. Unlike their predecessors in earlier waves of migration who were mainly poor and uneducated, ${ }^{39}$ many of the new Chinese migrants are the highly educated

35 Jens Hainmueller and Daniel J. Hopkins, "Public Attitudes Toward Immigration," Annual Review of Political Science 17, 1 (May 11, 2014): 225-49, doi:10.1146/annurev-polisci -102512-194818.

36 Jens Hainmueller and Michael J. Hiscox, "Educated Preferences: Explaining Attitudes Toward Immigration in Europe," International Organization 61, 2 (April 2007), doi:10.1017/ Soo20818307070142; Alin M. Ceobanu and Xavier Escandell, "Comparative Analyses of Public Attitudes Toward Immigrants and Immigration Using Multinational Survey Data: A Review of Theories and Research," Annual Review of Sociology 36, 1 (2010): 309-28, doi:10.1146/annurev.soc.012809.102651.

37 Ceobanu and Escandell, "Comparative Analyses of Public Attitudes Toward Immigrants and Immigration Using Multinational Survey Data."

38 Giovanni Facchini and Anna Maria Mayda, "Does the Welfare State Affect Individual Attitudes toward Immigrants? Evidence across Countries," Review of Economics and Statistics 91, 2 (May 1, 2009): 295-314, doi:10.1162/rest.91.2.295.

39 Leo Suryadinata, The Rise of China and the Chinese Overseas: A Study of Beijing's Changing Policy in Southeast Asia and Beyond (Singapore: ISEAS-Yusof Ishak Institute, 2017). 
or entrepreneurs who pursued investment in Southeast Asia, South Africa and Latin America as a result of China's overseas economic expansion since the 199os. Given the findings that skilled migrants contribute to increasing employment, capital accumulation and income in destination countries, ${ }^{40}$ public opinions in the овов countries towards the new, highly skilled Chinese migrants can be positive. On the other hand, the mobility of Chinese laborers can stir up negative attitudes among low-skilled workers in the destination countries who fear competition for low-wage jobs. In particular, the fact that Chinese firms such as those involved in infrastructure, oil and mining operations in Africa often hire Chinese contract laborers along with local labor can create resentment amidst high levels of unemployment found in many African countries. ${ }^{41}$ How the public in the овов countries view Chinese migrants thus depends considerably on who the migrants are and which segment of the local population is being considered.

Despite China's emerging role as an important source of migrants in African and Asian countries, there are not many empirical studies that directly consider how Chinese migrants are perceived in these countries. Given the growing economic influence of China on Africa, however, a few opinion surveys have been carried out to evaluate Africans' perception about Chinese engagement with their respective countries. Generally, African perceptions on China-Africa relations and the impact of China are positive and friendly. ${ }^{42}$ This is reflected in the recent Afrobarometer Survey conducted in 2014-2015 in 36 countries in Africa which included a series of questions related to perceptions about China's influence. Figure 3 presents the proportion of the respondents reporting positive or very positive attitude towards China's economic and political influence in their own country. ${ }^{43}$ Although there is a substantial variation across countries ranging from $33.2 \%$ in Algeria to $50.2 \%$ in Malawi and 92.1\% in Mali, on the average China's image is quite positive (62.1\%).

40 Francesc Ortega and Giovanni Peri, "The Causes and Effects of International Migrations: Evidence from oecd Countries 1980-2005," NBer Working Paper No. 14833 (Davis, CA: University of California, Davis, 2009), http://www.nber.org/papers/w14833.

41 Park, "Chinese Migration in Africa."

42 Barry Sautman and Yan Hairong, "African Perspectives on China-Africa Links," The China Quarterly 199 (September 2009): 728-59, doi:10.1017/So30574100999018X; Fei-Ling Wang and Esi A. Elliot, "China in Africa: Presence, Perceptions and Prospects," Journal of Contemporary China 23, 90 (November 2, 2014): 1012-32, doi:10.1080/10670564.2014.898888.

43 Afrobarometer, “Afrobarometer Data, 36 Countries, Round 6, Year 2014/2015," 2016, http:// afrobarometer.org. 


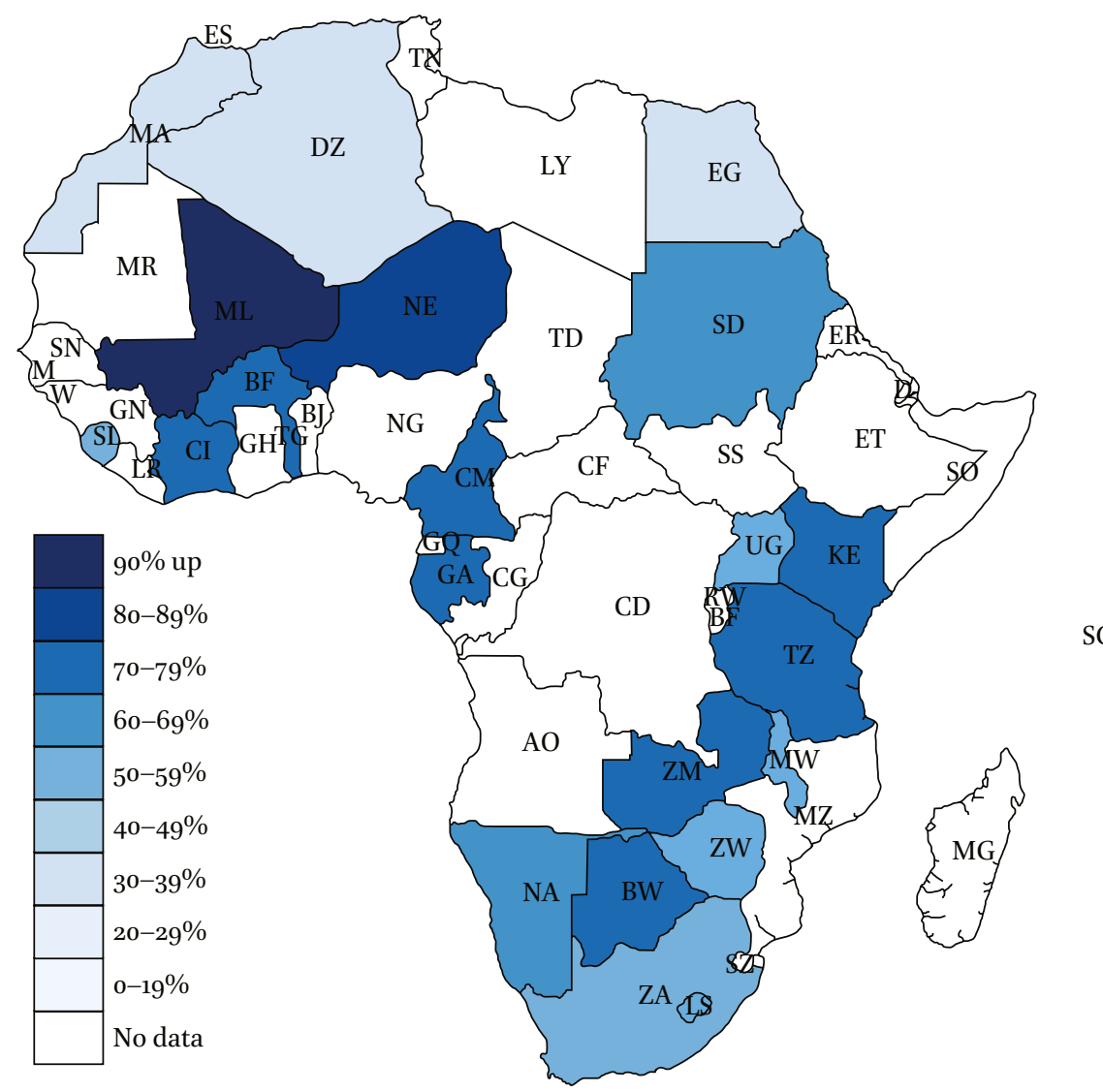

FIGURE 3 Percentages of respondents reporting positive attitude toward China's economic and political influence in own country.

SOURCE: AFROBAROMETER SURVEYS 2014/2015.

Likewise, China's increasing foreign investment and infrastructure development projects in the овов countries can influence public opinions towards China in these countries in a positive way. Figure 4 presents the proportion of respondents in 40 countries who reported somewhat favorable or very favorable opinion of China in 2015. ${ }^{44}$ Indeed, in many овов countries together with African countries where Chinese foreign direct investment is significant, the vast majority of respondents had positive attitude toward China ranging from $52 \%$ in Lebanon, $63 \%$ in Indonesia to $82 \%$ in Pakistan. Notwithstanding, the positive attitude toward China is below $50 \%$ for some Belt and Road countries such as India (41\%), Jordan (33\%), Vietnam (19\%) and Turkey (18\%).

44 Pew Research Center, “2015 Global Attitudes Survey," 2015, http://www.pewresearch.org. 


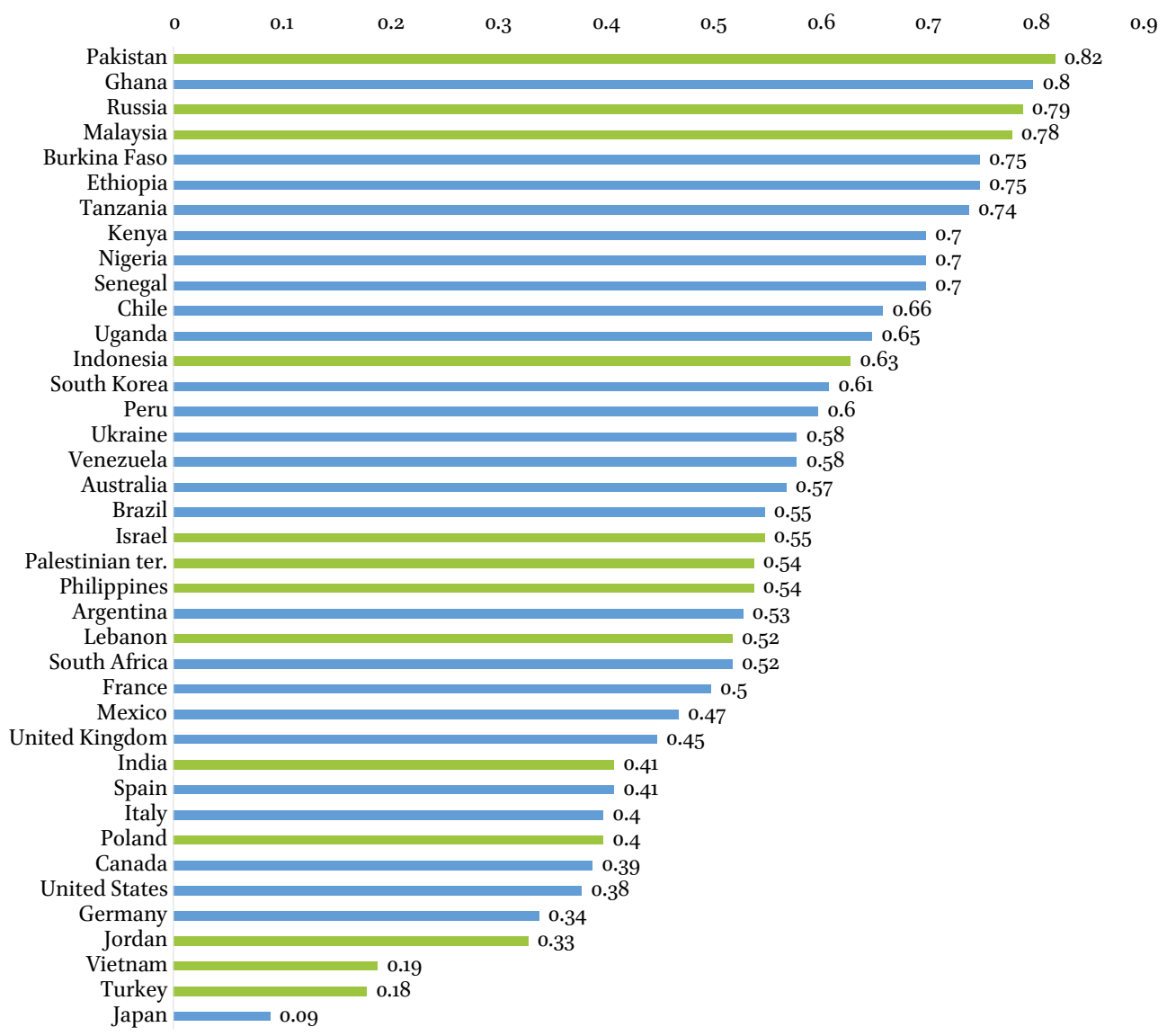

FIGURE 4 Percentages of respondents reporting favorable opinion of China, 2015. SOURCE: PEW RESEARCH CENTER 2015 GLOBAL ATTITUDES SURVEY.

China's recent territorial disputes with Vietnam and ongoing border disputes with India partly explain the low level of favorable opinion on China in these countries.

Certainly, foreign direct investment is not the only factor influencing public attitudes towards China. While the growth rate in Africa is partially attributed to China's increased trade and investment since $2000,{ }^{45}$ wealth is not necessarily distributed evenly. Similarly, in the овов countries, benefits from China's investment will vary with economic sectors and population subgroups. This has been the case in sub-Saharan Africa where the increase in trade with

45 Wenjie Chen, David Dollar, and Heiwai Tang, "Why Is China Investing in Africa? Evidence from the Firm Level" (IMF, 2015). 
China, especially in terms of natural resources, also came along with imports in cheaper manufacturing goods, putting pressure on African manufacturing sectors. ${ }^{46}$ Likewise, in Central Asia the presence of Chinese consumer goods, Chinese migrants and investments are occasionally contested, as can be seen in such examples as anti-Chinese demonstrations in Kazakhstan and public resentment against discriminatory policies against Uyghurs in Xinjiang. ${ }^{47}$ The public opinion in овов countries towards China thus will depend on the nature of investment, domestic economics and politics as well as the country's specific historical relationship with China.

Although the above surveys provide some ideas about how China is viewed globally, to my knowledge, there are no cross-national surveys that explicitly ask the public about their opinions towards Chinese migration or Chinese migrants. The generally favorable opinion on China and its accompanying economic investment may not translate into the same attitude toward Chinese migrants themselves. Kaplinsky ${ }^{48}$ suggests that different levels of acceptance towards Chinese migrants depend on differential impacts on subgroups of populations in the destination country. Who gets affected by economic competition or benefits from the presence of Chinese investment, projects and migration determines the relations between migrants and the host society members.

Likewise, there is no clear pattern to how Chinese migrants are integrated into the host society. The relations between Chinese migrants and the natives are likely to be subject to the type of migration and the nature of their work. For example, Chinese contract workers in construction projects in Vietnam typically live in dormitories provided by the employer or move from one project site to another. ${ }^{49}$ Naturally, these migrants have limited interactions with local communities. While Chinese entrepreneurs engaging in trade, services and light manufacturing businesses in Africa are expected to contribute to the local economy such as through offering employment opportunities and technology transfer, such interaction is also fairly limited..$^{50}$ The settlement of

46 Drummond and Xue Liu, "Africa's Rising Exposure to China: How Large Are Spillovers Through Trade?"

47 M. Laruelle and S. Peyrouse, The Chinese Question in Central Asia: Domestic Order, Social Change and the Chinese Factor (New York, NY: Columbia University Press, 2012).

48 "What Does the Rise of China Do for Industrialisation in Sub-Saharan Africa?," Review of African Political Economy 35, 115 (2008): 7-22.

49 Nguyen Van Chinh, "Recent Chinese Migration to Vietnam," Asian and Pacific Migration Journal 22, 1 (March 1, 2013): 7-30, doi: 10.1177/011719681302200102.

5o Haiyan Zhang, "The Role of Migration in Shaping China's Economic Relations with Its Main Partners," in Chinese Migration and Economic Relations with Europe, ed. Marco 
Chinese migrants in Asia and Africa described by several studies appears to be in the form of ethnic enclaves where the migrants live isolatedly from the locals, only consume Chinese products (e.g. food, DVDs and social media) and maintain strong ties with their family back in China. ${ }^{51}$ Suryadinata ${ }^{52}$ explains that the relatively poor integration of new Chinese migrants, especially the wealthy and highly skilled individuals who emigrated after the liberalization of China's emigration policies after 1980 is partly due to their capacity to move back and forth between China and the host country. Poorer migrants in the early migration waves, on the other hand, were more likely to remain in the host country since they could not afford to return to China, and eventually were integrated into local society. This suggests that the patterns of integration also depend considerably on the socioeconomic characteristics of the migrants. In fact, some studies find that Chinese migrants working in small-to medium-sized enterprises are more likely to live among Africans and learn local languages than Western expats. ${ }^{53}$

Given that most studies on Chinese migration are carried out on a local scale, it is not possible to draw a systematic conclusion of how Chinese migrants fare in the host societies. Similarly, how the new Chinese migrants associated with the Belt and Road initiative will be integrated in the овов countries depends considerably on the nature of their migration and their socioeconomic characteristics as well as on the socio-political climate in the destination countries. This calls for future research to pay particular attention to the heterogeneity of the Chinese migrants: who they are, what type of migration they are engaged in and where they go to. Furthermore, different dimensions of integration should be considered. Examples include language skills, housing, children's education, intermarriage and labor market participation. Large-scale surveys of Chinese migrants across овов countries will also provide a systematic overview of Chinese settlement patterns in these countries.

Sanfilippo and Agnieszka Weinar (New York, NY: Routledge, 2015), 33-54, http://cadmus. eui.eu//handle/1814/37216.

51 Ching Kwan Lee, "Raw Encounters: Chinese Managers, African Workers and the Politics of Casualization in Africa's Chinese Enclaves," The China Quarterly 199 (September 2009): 647-66, doi:10.1017/So305741009990142; Danielle Tan, "Small Is Beautiful': Lessons from Laos for the Study of Chinese Overseas," Journal of Current Chinese Affairs 41, 2 (July 10, 2012): 61-94; Howard W. French, China's Second Continent: How a Million Migrants Are Building a New Empire in Africa, First Edition (New York: Knopf, 2014).

$5^{2} \quad$ Ibid.

53 Sautman and Yan, "Localizing Chinese Enterprises in Africa." 


\section{Conclusion}

No doubt, it is too early to draw any conclusions on the implications of One Belt, One Road strategies on Chinese migration. Drawing upon the experience of the "Going Out" strategy which results in increases in China's foreign direct investment and trade overseas, one may expect a subsequent rise in international migration of Chinese laborers and entrepreneurs in the овоR countries. How these migrants will be integrated in the овов countries is likely to depend upon many factors - both the individual characteristics of the migrants themselves and contextual characteristics of the host society. In order to pinpoint the consequences of the овоR strategy on Chinese migration requires improvement of current research on Chinese migration and Chinese overseas. Identifying the research gaps such as the lack of accurate data on the distribution and composition of Chinese emigrants and scarce empirical studies on Chinese migrants' integration thus can help develop relevant research questions and improve research design on the topic of Chinese migration in the Belt and Road countries.

In particular, to understand the trends and patterns of Chinese migration as well as how migrants in the овов countries fare requires better official migration data and more precise estimates of migration flows which also account for undocumented workers. Digital records, social media data or mobile network data can potentially be an alternative source to capture mobility patterns and social networks of migrants. It is equally important to know the demographic and socioeconomic composition and distribution of the migrants. This information is fundamental for studying how the members of the Belt and Road countries perceive Chinese migrants and how integrated the migrants are in the destination country. Given that economic activities associated with the овов strategy will involve not only the large-scale publicly funded projects but also private and small-scale enterprises in addition to individual economic migrants, this diversity needs to be taken into account when studying the implications of Chinese migration in the Belt and Road countries.

\section{Acknowledgements}

I am grateful to Anne Goujon and the two anonymous referees for their helpful suggestions and comments to improve this paper. I would also like to thank Wei Qi for his assistance with Chinese translation of the abstract and my biosketch. 


\section{Bibliography}

Abel, Guy J. "Estimates of Global Bilateral Migration Flows by Gender between 1960 and 2015." International Migration Review (2017), doi:10.1111/imre.12327.

Abel, Guy J. "Estimating Global Migration Flow Tables Using Place of Birth Data." Demographic Research 28, 18 (March 15, 2013): 505-46. doi: 10.4054/DemRes. 2013.28.18.

Abel, Guy J., and Nikola Sander. "Quantifying Global International Migration Flows." Science 343, 6178 (March 2014): 1520-22. doi: 10.1126/science.1248676.

Afrobarometer. “Afrobarometer Data, 36 Countries, Round 6, Year 2014/2015," 2016. http://afrobarometer.org.

Besada, Hany, Yang Wang, and John Whalley. "China's Growing Economic Activity In Africa." In China's Integration into the World Economy, edited by John Whalley, 221-54. Singapore: World Scientific, 2011. https://ideas.repec.org/h/wsi/wschap/ 9789814304795_ooog.html.

Ceobanu, Alin M., and Xavier Escandell. "Comparative Analyses of Public Attitudes Toward Immigrants and Immigration Using Multinational Survey Data: A Review of Theories and Research." Annual Review of Sociology 36, 1 (2010): 309-28. doi: 10.1146/ annurev.soc.012809.102651.

Chen, Chuan, Andrea Goldstein, and Ryan Orr. "Local Operations of Chinese Construction Firms in Africa: An Empirical Survey." The Journal of Construction Management, (2009): $75^{-89}$.

Chen, Wenjie, David Dollar, and Heiwai Tang. "Why Is China Investing in Africa? Evidence from the Firm Level." IMF, 2015.

Debnath, Priyanka. "Leveraging Return Migration for Development: The Role of Countries of Origin." KNOMAD Working Paper Series. Washington, DC: Global Knowledge Partnership on Migration and Development (KNOMAD), 2016. http://www.knomad. org/docs/integration_issues/WP\%2oLeveraging\%2oReturn\%2oMigration\%2o for\%2oDevelopment $\% 20-\% 20$ The $\% 20$ Role $\% 200 f \% 20$ Countries $\% 200 f \% 20$ Origin. pdf.

Deville, Pierre, Catherine Linard, Samuel Martin, Marius Gilbert, Forrest R. Stevens, Andrea E. Gaughan, Vincent D. Blondel, and Andrew J. Tatem. "Dynamic Population Mapping Using Mobile Phone Data." Proceedings of the National Academy of Sciences 111, 45 (November 11, 2014): 15888-93. doi: 10.1073/pnas.1408439111.

Dobler, Gregor. "Chinese Shops and the Formation of a Chinese Expatriate Community in Namibia." The China Quarterly, no. 199 (2009): 707-27.

Drummond, Paulo, and Estelle Xue Liu. "Africa's Rising Exposure to China: How Large Are Spillovers Through Trade?" Im F Working Paper. Washington, DC: International Monetary Fund, November 2013. https://www.imf.org/external/pubs/ft/wp/2013/ wp13250.pdf. 
Economy, Elizabeth. "China's Rise in Southeast Asia: Implications for the United States." Journal of Contemporary China 14, 44 (August 1, 2005): 409-25. doi: 10.1080/ 10670560500115184 .

Facchini, Giovanni, and Anna Maria Mayda. "Does the Welfare State Affect Individual Attitudes toward Immigrants? Evidence across Countries." Review of Economics and Statistics 91, 2 (May 1, 2009): 295-314. doi: 10.1162/rest.91.2.295.

Fielding, Tony. Asian Migrations: Social and Geographical Mobilities in Southeast, East, and Northeast Asia. New York, NY: Routledge, 2015.

French, Howard W. China's Second Continent: How a Million Migrants Are Building a New Empire in Africa. First Edition. New York: Knopf, 2014.

Hainmueller, Jens, and Michael J. Hiscox. "Educated Preferences: Explaining Attitudes Toward Immigration in Europe." International Organization 61, 2 (April 2007). doi: 10.1017/Soo20818307070142.

Hainmueller, Jens, and Daniel J. Hopkins. "Public Attitudes Toward Immigration." Annual Review of Political Science 17, 1 (May 11, 2014): 225-49. doi: 10.1146/annurevpolisci-102512-194818.

Jenkins, Rhys, and Chris Edwards. "The Economic Impacts of China and India on SubSaharan Africa: Trends and Prospects." Journal of Asian Economics 17, 2 (April 2006): 207-25. doi: 10.1016/j.asieco.2006.02.002.

Kaplinsky, Raphael. "What Does the Rise of China Do for Industrialisation in SubSaharan Africa?" Review of African Political Economy 35, 115 (2008): 7-22.

Kaplinsky, Raphael, and Mike Morris. "Chinese FDI in Sub-Saharan Africa: Engaging with Large Dragons." The European Journal of Development Research 21, 4 (September 1, 2009): 551-69. doi: 10.1057/ejdr.2009.24.

Laruelle, M., and S. Peyrouse. The Chinese Question in Central Asia:Domestic Order, Social Change and the Chinese Factor. New York, NY: Columbia University Press, 2012.

Lee, Ching Kwan. "Raw Encounters: Chinese Managers, African Workers and the Politics of Casualization in Africa's Chinese Enclaves." The China Quarterly 199 (September 2009): 647-66. doi: 10.1017/So305741009990142.

Ma, Laurence J.C. "Space Place and Transnationalism in the Chinese Diaspora." In The Chinese Diaspora: Space, Place, Mobility, and Identity, edited by Laurence J.C. Ma and Carolyn L. Cartier, 1-50. Lanham, MD: Rowman \& Littlefield, 2002.

Mohan, Giles and May Tan-Mullins, "Chinese Migrants in Africa as New Agents of Development? An Analytical Framework.” In The Power of the Chinese Dragon: Implications for African Development and Economic Growth, edited by Spencer Henson and O. Fiona Yap. Vol. 3 of Palgrave Readers in Economics, 174-98. London: Palgrave Macmillan UK, 2016.

Mohan, Giles, May Tan-Mullins, Ben Lampert, and Daphine Chang. Chinese Migrants and Africa's Development: New Imperialists or Agents of Change? London: Zed Books Ltd, 2014 . 
Mung, Emmanuel Ma. "Chinese Migration and China Foreign Policy in Africa." Journal of Chinese Overseas 4, 1 (May 1, 2008): 91-109. doi: 10.1163/179325408788691471.

NDRC. "Vision and Actions on Jointly Building Silk Road Economic Belt and 21stCentury Maritime Silk Road." Beijing: National Development and Reform Commission (NDRC), March 28, 2015. http://en.ndrc.gov.cn/newsrelease/201503/ t20150330_669367.html.

Ortega, Francesc, and Giovanni Peri. "The Causes and Effects of International Migrations: Evidence from OECD Countries 1980-2005." NBER Working Paper No. 14833. Davis, CA: University of California, Davis, 2009. http://www.nber.org/papers/w14833. Park, Yoon Jung. "Chinese Migration in Africa." China in Africa Project. South African Institute of International Affairs, 2009. https://www.saiia.org.za/occasional-papers/ 132-chinese-migration-in-africa/file.

Pew Research Center. “2015 Global Attitudes Survey," 2015. http://www.pewresearch .org.

Peyrouse, Sébastien. "Discussing China: Sinophilia and Sinophobia in Central Asia." Journal of Eurasian Studies 7, 1 (January 2016): 14-23. doi: 10.1016/j.euras.2015.10 .003 .

Sautman, Barry, and Yan Hairong. "African Perspectives on China-Africa Links." The China Quarterly 199 (September 2009): 728-59. doi: 10.1017/So30574100999018X.

Sautman, Barry, and Hairong Yan. "Localizing Chinese Enterprises in Africa: From Myths to Policies." HKUST IEMs Thought Leadership Brief Series. HKUST Institute for Emerging Market Studies, February 2015. http://econpapers.repec.org/paper/ hkubriefs/201505.htm.

Suryadinata, Leo. The Rise of China and the Chinese Overseas: A Study of Beijing's Changing Policy in Southeast Asia and Beyond. Singapore: ISEAS-Yusof Ishak Institute, 2017.

Tan, Danielle. 'Small Is Beautiful': Lessons from Laos for the Study of Chinese Overseas." Journal of Current Chinese Affairs 41, 2 (July 10, 2012): 61-94.

United Nations. "Trends in International Migrant Stock: Migrants by Destination and Origin." New York: United Nations, Department of Economic and Social Affairs, 2015. http://www.un.org/en/development/desa/population/migration/data/ estimates2/estimates15.shtml.

Van Chinh, Nguyen. "Recent Chinese Migration to Vietnam." Asian and Pacific Migration Journal 22, 1 (March 1, 2013): 7-30. doi: 10.1177/011719681302200102.

Wang, Fei-Ling, and Esi A. Elliot. "China in Africa: Presence, Perceptions and Prospects." Journal of Contemporary China 23, 90 (November 2, 2014): 1012-32. doi:10. 1080/10670564.2014.898888.

Xiang, Biao. "Emigration Trends and Policies in China: Movement of the Wealthy and Highly Skilled." Transatlantic Council on Migration. Washington, DC: Migration Policy, February 5, 2016. http://www.migrationpolicy.org/research/emigration -trends-and-policies-china-movement-wealthy-and-highly-skilled. 
Xiang, Biao. "The Rise of China, Changing Patterns of out-Migration and Identity Implications." In Handbook of Chinese Migration: Identity and Wellbeing, edited by Robyn R. Iredale and Fei Guo, 278-94. Cheltenham, U K: Edward Elgar Publishing, 2015.

Yeh, Emily T., and Elizabeth Wharton. "Going West and Going Out: Discourses, Migrants, and Models in Chinese Development." Eurasian Geography and Economics 57, 3 (May 3, 2016): 286-315. doi:10.1080/15387216.2016.1235982.

Zafar, Ali. "The Growing Relationship Between China and Sub-Saharan Africa: Macroeconomic, Trade, Investment, and Aid Links." The World Bank Research Observer 22, 1 (March 1, 2007): 103-30. doi:10.1093/wbro/lkmoo1.

Zagheni, Emilio, and Ingmar Weber. "You Are Where You E-Mail: Using E-Mail Data to Estimate International Migration Rates." In Proceedings of the 4th Annual AcM Web Science Conference, 348-351. ACM, 2012. http://dl.acm.org/citation.cfm?id=2380764. Zhang, Haiyan. "The Role of Migration in Shaping China's Economic Relations with Its Main Partners." In Chinese Migration and Economic Relations with Europe, edited by Marco Sanfilippo and Agnieszka Weinar, 33-54. New York, NY: Routledge, 2015. http://cadmus.eui.eu//handle/1814/37216.

Zhuang, Guotu, and Wang Wangbo. "Migration and Trade: The Role of Overseas Chinese in Economic Relations between China and Southeast Asia." International Journal of China Studies 1, 1 (2010): 174-93. 